\title{
Calcium-binding capacity of organic and inorganic ortho- and polyphosphates
}

\author{
Esther De Kort ${ }^{1 *}$, Marcel Minor ${ }^{1}$, Thom SnOeren ${ }^{1}$, Toon VAn Hoolddonk ${ }^{2}$, \\ Erik VAN DER LINDEN ${ }^{3}$ \\ ${ }^{1}$ Processing and New Technologies, Danone Research - Centre for Specialized Nutrition, \\ Bosrandweg 20, 6704 PH Wageningen, The Netherlands \\ ${ }^{2}$ Dairy Science and Technology Group, Department of Agrotechnology and Food Sciences, \\ Wageningen University, Bomenweg 2, 6703 HD Wageningen, The Netherlands \\ ${ }^{3}$ Food Physics Group, Department of Agrotechnology and Food Sciences, Wageningen University, \\ Bomenweg 2, 6703 HD Wageningen, The Netherlands
}

\section{Received 29 September 2008 - Accepted 3rd February 2009}

\begin{abstract}
The aim of this research was to determine the calcium-binding capacity of inorganic and organic ortho- and polyphosphates. This calcium-binding capacity can be used to influence the stability of, for example, casein micelles in dairy systems. Four phosphates were selected: disodium uridine monophosphate $\left(\mathrm{Na}_{2} \mathrm{UMP}\right.$, organic orthophosphate), disodium hydrogen phosphate $\left(\mathrm{Na}_{2} \mathrm{HPO}_{4}\right.$, inorganic orthophosphate), sodium phytate (SP, organic polyphosphate), and sodium hexametaphosphate (SHMP, inorganic polyphosphate). Concentrations of up to $100 \mathrm{mmol} \cdot \mathrm{L}^{-1}$ phosphate were added to a $50 \mathrm{mmol} \cdot \mathrm{L}^{-1} \mathrm{CaCl}_{2}$ solution. The samples were prepared at $\mathrm{pH} 8.0$ and were analyzed before and after sterilization for calcium-ion activity, conductivity, $\mathrm{pH}$, sediment, and turbidity. Both SHMP and SP are strong chelators, as calcium ions bind to these phosphates in the ratio of 3:1 and 6:1, respectively. Calcium ions also strongly bind to $\mathrm{Na}_{2} \mathrm{HPO}_{4}$, but in a ratio of $3: 2$ with insoluble $\mathrm{Ca}_{3}\left(\mathrm{PO}_{4}\right)_{2}$ complexes as result. The equilibrium position of $\mathrm{Na}_{2} \mathrm{UMP}$ is not strong towards the chelated complex, and significant levels of free calcium and free phosphate can exist. An equilibrium constant of $0.29 \pm 0.08 \mathrm{~L} \cdot \mathrm{mol}^{-1}$ was determined for calcium uridine monophosphate (CaUMP) complexes. Both calculation of the equilibrium constant and analysis on the CaUMP precipitate confirmed a reactivity of $1: 1$ between calcium and $\mathrm{Na}_{2} \mathrm{UMP}$. The CaUMP complexes are well soluble at ambient temperature, and insoluble complexes appear after sterilization, because the solubility of CaUMP decreases during heating. Finally, we concluded that the structure of phosphate molecules determines their calcium-binding capacity rather than organic or inorganic origin of phosphates.
\end{abstract}

orthophosphate / polyphosphate / organic phosphate / inorganic phosphate / calcium

摘要 - 有机和无机正磷酸盐和多磷酸盐对钻的结合能力。本文测定了无机和有机正磷酸 和多磷酸盐对钙的结合能力。这种结合能力影响到乳体系中酪蛋白酪胶束的稳定。四种 磷酸盐分别为: 尿苷磷酸二钠 $\left(\mathrm{Na}_{2} \mathrm{UMP}\right.$, 有机正磷酸盐), 磷酸氢二钠 $\left(\mathrm{Na}_{2} \mathrm{HPO}_{4}\right.$, 无 机正磷酸盐), 肌醇六磷酸钠 (SP, 有机多磷酸盐)和六偏磷酸钠 (SHMP, 无机多磷酸盐)。 $100 \mathrm{mmol} \cdot \mathrm{L}^{-1}$ 的磷酸盐添加到 $50 \mathrm{mmol} \cdot \mathrm{L}^{-1}$ 的 $\mathrm{CaCl}_{2}$ 溶液中。分析了杀菌前后样品在 $\mathrm{pH} 8.0$ 的钙离子活度、电导率、 $\mathrm{pH}$ 值、沉淀值和浊度。SHMP 和 SP 都是强鳌合剂, 钙离 子与这些磷酸盐螯合的比分别为 3:1 和 $6: 1$ 。同时, 钲离子与 $\mathrm{Na}_{2} \mathrm{HPO}_{4}$ 结合能力较强, 产 生了 $3: 2$ 的不溶性 $\mathrm{Ca}_{3}\left(\mathrm{PO}_{4}\right)_{2}$ 混合物。平衡状态下的 $\mathrm{Na}_{2} \mathrm{UMP}$ 不能与钙形成稳定的螯合物, 存

*Corresponding author (通讯作者): Esther.dekort@danone.com 
在大量的游离钙离子和磷酸盐。C CaUMP 螯合物的平衡常数为 $0.29 \pm 0.08 \mathrm{~L} \cdot \mathrm{mol}^{-1}$ 。通过 CaUMP 沉淀反应平衡常数的计算证实了钻和 $\mathrm{Na}_{2} \mathrm{UMP}$ 之间的反应比例为 $1: 1$ 。因为在加热过程 中 CaUMP 的溶解度减小, 所以尿苷酸钻复合物 (CaUMP) 在室温下易溶, 但灭菌后则出现不溶 性复合物。因此, 磷酸盐对钲结合能力取决于其分子结构, 而不是磷酸盐中的有机或无机分子。

\section{$\mathrm{Na}_{2} \mathrm{UMP} / \mathrm{Na}_{2} \mathrm{HPO}_{4}$ / 六偏磷酸钠 / 肌醇六磷酸钠 / 钻}

Résumé - Capacité de liaison du calcium des orthophosphates et polyphosphates organiques et inorganiques. Le but de cette recherche était de déterminer la capacité de liaison du calcium des orthophosphates et polyphosphates inorganiques et organiques. Cette capacité de liaison du calcium peut être utilisée pour influencer la stabilité des micelles de caséine dans les systèmes laitiers. Quatre phosphates ont été sélectionnés : l'uridine monophosphate disodique $\left(\mathrm{Na}_{2} \mathrm{UMP}\right.$, orthophosphate organique), l'hydrogenophosphate disodique $\left(\mathrm{Na}_{2} \mathrm{HPO}_{4}\right.$, orthophosphate inorganique), le phytate de sodium (SP, polyphosphate organique) et l'hexametaphosphate de sodium (SHMP, polyphosphate inorganique). Des concentrations de phosphate allant jusqu'à $100 \mathrm{mmol} \cdot \mathrm{L}^{-1}$ ont été ajoutées à une solution contenant $50 \mathrm{mmol} \cdot \mathrm{L}^{-1}$ de calcium. Les échantillons préparés à $\mathrm{pH} 8,0$ ont été analysés avant et après stérilisation pour l'activité de l'ion calcium, la conductivité, le $\mathrm{pH}$, le sédiment et la turbidité. SHMP et SP sont tous les deux des chélateurs forts, puisque les ions calcium sont liés à ces phosphates dans un ratio 3:1 et 6:1 respectivement. Les ions calcium sont aussi fortement liés au $\mathrm{Na}_{2} \mathrm{HPO}_{4}$, mais dans un ratio de $3: 2$, résultant dans la formation de complexes insolubles de $\mathrm{Ca}_{3}\left(\mathrm{PO}_{4}\right)_{2}$. Le Na $\mathrm{NM}_{2} \mathrm{UM}$ n'est pas aussi fortement complexé et des taux significatifs de calcium libre et de phosphate libre peuvent exister. Une constante d'équilibre de $0,29 \pm 0,08 \mathrm{~L} \cdot \mathrm{mol}^{-1}$ a été déterminée pour les complexes d'uridine monophosphate de calcium (CaUMP). Le calcul de la constante d'équilibre et l'analyse du précipité de CaUMP ont confirmé l'un et l'autre une réactivité de 1:1 entre le calcium et le $\mathrm{Na}_{2} \mathrm{UMP}$. Les complexes CaUMP sont bien solubles à température ambiante mais des complexes insolubles apparaissent après stérilisation parce que la solubilité du CaUMP diminue au cours du chauffage. Finalement, nous pouvons conclure que la structure des molécules de phosphate détermine leur aptitude à lier le calcium plus que l'origine organique ou inorganique des phosphates.

orthophosphate / polyphosphate / phosphate organique / phosphate inorganique / calcium

\section{INTRODUCTION}

Calcium and phosphate are the most relevant minerals in dairy and medical nutrition products, and are part of the colloidal calcium phosphate (CCP) in casein micelles. CCP is important for the micelle structure and (heat) stability of dairy products [34]. Addition of calcium and phosphate causes interactions with casein micelles, CCP, and soluble calcium phosphate. As a result, insoluble or soluble calcium phosphate complexes will be formed $[1,4,14,20,21,29]$. Many calciumbinding agents are used in the dairy industry, for example, citrate, polyphosphates, or pyrophosphates, and they are named chelators $[4,18]$. These chelators influence the activity of calcium in solution, the CCP concentration, and thus the (heat) stability of casein micelles in dairy systems [4]. Disodium hydrogen phosphate $\left(\mathrm{Na}_{2} \mathrm{HPO}_{4}\right)$ and sodium hexametaphosphate (SHMP) are examples of chelating inorganic phosphates, which are commonly used in dairy products to influence and improve the quality of, for example, evaporated milk, processed cheese, or calcium-enriched milk [33]. $\mathrm{Na}_{2} \mathrm{HPO}_{4}$ and SHMP are ortho- and polyphosphates, respectively (Fig. 1), and $\mathrm{Na}_{2} \mathrm{HPO}_{4}$ (Fig. 1a) influences casein micelles by interacting with casein or CCP [4]. Upreti et al. [30] and Pyne [22] summarized that $\mathrm{CCP}$ is composed of $\mathrm{CaHPO}_{4}$, $\mathrm{Ca}_{3}\left(\mathrm{PO}_{4}\right)_{2}$, and even larger complexes including those containing crystal water. This indicates that calcium and $\mathrm{Na}_{2} \mathrm{HPO}_{4}$ react in a ratio of $1: 1$ or $3: 2$ around $\mathrm{pH}$ 6.7. Also, SHMP (Fig. 1b) influences the amount of $\mathrm{CCP}$ present in casein 
(a)

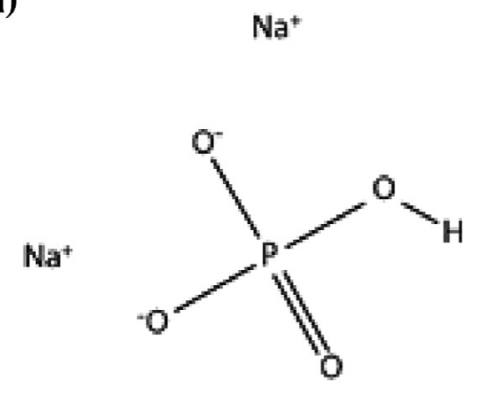

(b)<smiles>O=P1([O-])OP(=O)([O-])OP(=O)([O-])OP(=O)([OH2+])OP(=O)([O-])OP(=O)([O-])O1</smiles>

(c)

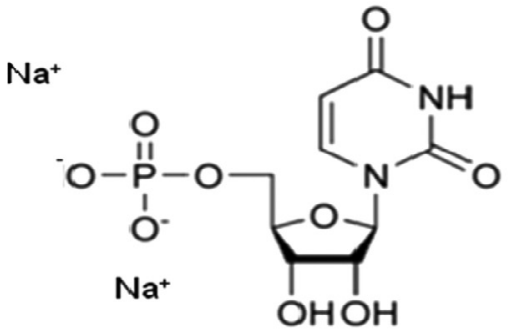

Figure 1. Phosphates used in this study: (a) $\mathrm{Na}_{2} \mathrm{HPO}_{4}$ (d)

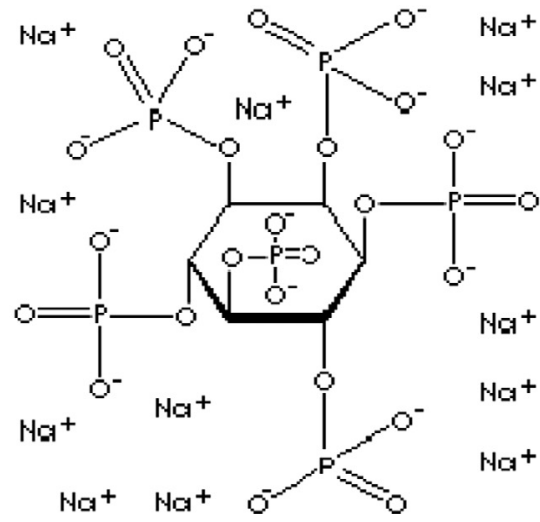

(b) SHMP; (c) $\mathrm{Na}_{2} \mathrm{UMP}$; and (d) SP.

micelles by binding calcium ions [14-17]. SHMP is a strong chelator and its binding to polyvalent cations is equal for calcium, magnesium, strontium, and barium [32]. Calcium hexametaphosphate can also bind with casein micelles. The extent of interaction of polyphosphates is, in general, dependent on the chain length of the polyphosphate [32]. $\mathrm{Na}_{2} \mathrm{HPO}_{4}$ binds less strongly with calcium than SHMP, even when extremely high $\mathrm{Na}_{2} \mathrm{HPO}_{4}$ concentrations are used [14].

Nucleotides, such as disodium uridine monophosphate $\left(\mathrm{Na}_{2} \mathrm{UMP}\right)$ (Fig. 1c), are organic orthophosphates, which naturally occur in human milk at low concentrations and are added to baby food [19]. To our knowledge, no information is available about the interaction of $\mathrm{Na}_{2} \mathrm{UMP}$ with casein micelles. However, the interaction of multivalent cations with nucleotides has been studied in more detail $[7,9,13,23$, $25,26]$. These studies concluded that interaction with pyrimidine nucleotides $\left(\mathrm{Na}_{2} \mathrm{CMP}\right.$ and $\left.\mathrm{Na}_{2} \mathrm{UMP}\right)$ is solely determined by the alkalinity of the corresponding phosphate groups. This indicates that these pyrimidine molecules have a simple monophosphate group and that reactivity of $\mathrm{Na}_{2}$ UMP to cations should be similar to $\mathrm{Na}_{2} \mathrm{HPO}_{4}$.

Sodium phytate (SP) is an organic polyphosphate (Fig. 1d) and a strong chelator. It is naturally present in nuts, seeds, and grains, but is also added to foods as stabilizer, antioxidant, or preservative $[5,28]$. 
It has 12 negative charges and binds all multivalent cations [5]. Below the $\mathrm{pH}$ of $\sim 5.0$, no significant binding of calcium with phytate occurs, but between $\mathrm{pH} 5.0$ and 8.0 maximal calcium binding in the ratio of $6: 1$ occurs [12]. The solubility of these complexes show $\mathrm{pH}$-dependent variations and are further determined by the type of multivalent cations and ionic strength [5, 28]. Mono- and dicalcium phytate are soluble complexes, but addition of a third calcium ion causes precipitation. If calcium is present in excess, insoluble pentacalcium phytate dominates the precipitate [27]. SP binds calcium ions irreversible and also interacts with proteins by binding to free lysine residues [6]. In this way it can affect the stability of dairy systems by binding with calcium and/or protein.

Both SHMP and SP are thus very strong chelators and are expected to have a strong influence on (heat) stability of dairy products. In contrast, $\mathrm{Na}_{2} \mathrm{HPO}_{4}$ and $\mathrm{Na}_{2} \mathrm{UMP}$ bind less calcium ions at comparable concentrations and, consequently, are expected to have less influence on the (heat) stability of dairy systems. Interactions between calcium and these phosphates must be known to understand the interactions between calcium, phosphate, and casein during the processing of dairy products. The aim of this research was to determine the calciumbinding capacity of organic and inorganic ortho- and polyphosphates before and after sterilization. Sterilization is included in this research, as long shelf life dairy products, and especially medical nutrition, will undergo this heat treatment.

\section{MATERIALS AND METHODS}

Concentrations of up to $100 \mathrm{mmol} \cdot \mathrm{L}^{-1}$ phosphate were added to $50 \mathrm{mmol} \cdot \mathrm{L}^{-1}$ $\mathrm{CaCl}_{2}$ solution. Samples were prepared at pH 8.0; maximal calcium-phosphate interactions were expected at this $\mathrm{pH}$, resulting in soluble and insoluble calcium phosphate complexes. Samples were analyzed before and after sterilization for calcium-ion activity, conductivity, $\mathrm{pH}$, sediment, and turbidity.

\subsection{Sample preparation}

Stock solutions of $\mathrm{Na}_{2} \mathrm{UMP}$ (Yamasa Corporation, Chiba, Japan), $\mathrm{Na}_{2} \mathrm{HPO}_{4}$ (Merck \& Co. Inc., Darmstadt, Germany), SHMP (VWR International Ltd., Poole, England), phytic acid dodecasodium salt hydrate (Sigma-Aldrich GMBH, Steinheim, Germany), and calcium chloride (Kirsch Pharma GMHB, Salzgitter, Germany) were prepared using demineralized water. All stock solutions were adjusted to $\mathrm{pH} 8.0$ with $1 \mathrm{~mol} \cdot \mathrm{L}^{-1}$ sodium hydroxide (SigmaAldrich GMBH, Steinheim, Germany) or $1 \mathrm{~mol} \cdot \mathrm{L}^{-1}$ hydrochloric acid (Merck \& Co. Inc., Darmstadt, Germany). Subsequently, samples were prepared with $50 \mathrm{mmol} \cdot \mathrm{L}^{-1}$ $\mathrm{CaCl}_{2}$, to which concentration ranges of 0-100 $\mathrm{mmol} \cdot \mathrm{L}^{-1} \mathrm{Na}_{2} \mathrm{UMP}, 0-100 \mathrm{mmol} \cdot \mathrm{L}^{-1}$ $\mathrm{Na}_{2} \mathrm{HPO}_{4}, \quad 0-30 \mathrm{mmol} \cdot \mathrm{L}^{-1}$ SHMP, or 0-25 mmol. $\mathrm{L}^{-1} \mathrm{SP}$ were added. The $\mathrm{pH}$ of prepared samples, which represent $90 \%$ of the total volume at this moment, was measured and, if necessary, adjusted to $\mathrm{pH} 8.0 \pm 0.1$. After $1 \mathrm{~h}$, the samples were measured a second time and brought to $\mathrm{pH} 8.0 \pm 0.1$. Subsequently, demineralized water was added to obtain the required concentrations, and the final $\mathrm{pH}$ was measured. No $\mathrm{pH}$ adjustments were made anymore in case the final $\mathrm{pH}$ deviated from 8.0. Also, a concentration range of $0-160 \mathrm{mmol} \cdot \mathrm{L}^{-1}$ was made for $\mathrm{Na}_{2} \mathrm{UMP}$ in $20 \mathrm{mmol} \cdot \mathrm{L}^{-1}$ $\mathrm{CaCl}_{2}$ solution for further study of the calcium-binding capacity of $\mathrm{Na}_{2} \mathrm{UMP}$. All samples were prepared and analyzed at least in duplicate, and the samples were analyzed with and without a sterilization step. During the retort sterilization process, the samples were heated from 20 to $96{ }^{\circ} \mathrm{C}$ for $271 \mathrm{~s}$, followed by heating at $121^{\circ} \mathrm{C}$ for $960 \mathrm{~s}$, and finally cooling to $40{ }^{\circ} \mathrm{C}$ for $420 \mathrm{~s}$ 
(Stock, Grafton, USA). Samples were sterilized in $200 \mathrm{~mL}$ glass bottles with metal caps and were rotated during the process.

\section{2. $\mathrm{pH}$}

Titrations and $\mathrm{pH}$ measurements were done with a 718 Stat Titrino (Metrohm, Herisau, Switzerland). The instrument was calibrated with stock solutions at $\mathrm{pH} 4.0$ 7.0. Calibration and measurements were done at ambient temperature. Samples were adjusted to $\mathrm{pH} 8.0 \pm 0.1$. No buffering agents were added; as a consequence, when a $\mathrm{pH}$ change was observed in the final samples, no $\mathrm{pH}$ corrections were made.

\subsection{Conductivity}

The ion conductivity was measured with an ion conductivity meter (CLM 381, serial number 50081031, Endress and Hauser, Weil am Rhein, Germany). Measurements were performed at ambient temperature. The cell constant of the meter was $0.475 \mathrm{~cm}^{-1}$.

\subsection{Calcium-ion activity}

The calcium-ion activity was measured with a Mettler Toledo Seven Multi ${ }^{\mathrm{TM}}$ (with an Inlab ${ }^{\circledR}$ Expert Pro pH-meter) calcium measuring device (Mettler Toledo, Greifensee, Switzerland) using an Orion 9300BH electrode and an Orion 900100 reference electrode. Calibration was performed at ambient temperature with standard solutions containing 20,200, and $2000 \mathrm{mg} \cdot \mathrm{kg}^{-1}$ calcium (as $\mathrm{CaCl}_{2}$ ) and $80 \mathrm{mmol} \cdot \mathrm{L}^{-1} \mathrm{KCl}$. Addition of this monovalent background electrolyte is beneficial, as it keeps the calcium-ion activity coefficient effectively constant in the calibration solutions. A calcium-ion activity coefficient $\left(\gamma_{\mathrm{Ca}^{2+}}\right)$ of 0.29 was calculated for the calibration solutions using the formula of Davies $[3,24]$. The activity of calcium ions in each sample was determined by multiplying the experimental calcium-ion activities with the activity coefficient of 0.29 . Electrodes remained in the $200 \mathrm{mg} \cdot \mathrm{kg}^{-1}$ stock solution for $30 \mathrm{~min}$ before calibration was started. Every solution was measured during $5 \mathrm{~min}$ until equilibrium was reached. The results are expressed in calcium-ion activity $\left(\mathrm{mmol} \cdot \mathrm{L}^{-1}\right)$.

\subsection{Turbidity}

Turbidity was measured with a spectrophotometer (4053 Kinetics, LKB Biochrom, Midland, Canada). Plastic cuvettes of a length of $1 \mathrm{~cm}$ were used. Measurements were done at $700 \mathrm{~nm}$ and at ambient temperature.

\subsection{Sediment}

The amount of sediment was measured by filtering sample solutions through folded filters of Ø $185 \mathrm{~mm}$ type 5951/2 (Whatman, Schleider \& Schuell, Dassel, Germany). The filters were dried at $37^{\circ} \mathrm{C}$ for $48 \mathrm{~h}$ and weighed at ambient temperature to determine the amount of sediment in each filter. The amount of sediment is expressed as gram per $100 \mathrm{~g}$ solution.

\subsection{UMP and uridine determination}

UMP and uridine analyses were done with a reversed phase HPLC, using an Alltima C18 $5 \mu$ particles column $250 \times$ $4.6 \mathrm{~mm}$ with precolumn $7.5 \times 4.6 \mathrm{~mm}$ packed with the same material. Samples were prepared by addition of $800 \mu \mathrm{L} 0.1 \mathrm{~mol} \cdot \mathrm{L}^{-1}$ perchloric acid to $200 \mu \mathrm{L}$ liquid sample. Nucleotides were extracted by vortexing the solution, followed by centrifugation, and $500 \mu \mathrm{L}$ supernatant was neutralized with $20 \mu \mathrm{L} 2.3 \mathrm{~mol} \cdot \mathrm{L}^{-1}$ potassium hydrogen carbonate. HPLC elution was done with solvent $\mathrm{A}$, consisting of $0.15 \mathrm{~mol} \cdot \mathrm{L}^{-1}$ $\mathrm{NH}_{4} \mathrm{H}_{2} \mathrm{PO}_{4}$ solution containing $1 \%(\mathrm{v} / \mathrm{v})$ methanol at $\mathrm{pH} 6.1 \pm 0.05$, and solvent $\mathrm{B}$, 
consisting of $0.15 \mathrm{~mol} \cdot \mathrm{L}^{-1} \quad \mathrm{NH}_{4} \mathrm{H}_{2} \mathrm{PO}_{4}$ solution containing $40 \%(\mathrm{v} / \mathrm{v})$ methanol at $\mathrm{pH} 6.1 \pm 0.05$. Gradient elution was done by $0-360 \mathrm{~s} 100 \% \mathrm{~A}, 360-540 \mathrm{~s} 2.5 \% \mathrm{~B}$, 540-1140 s 20\% B, 1140-1260 s linear gradient to $80 \% \mathrm{~B}, 1260-1500 \mathrm{~s} 80 \% \mathrm{~B}$, $1500-1560 \mathrm{~s}$ linear gradient back to $100 \% \mathrm{~A}$ and $1560-2100 \mathrm{~s}$ re-equilibrate with $100 \% \mathrm{~A}$. Flow rate was $0.013 \mathrm{~mL} \cdot \mathrm{s}^{-1}$. Quantification was done at UV absorbance of 210 and $254 \mathrm{~nm}$ and comparison was done with UMP and uridine standards.

\subsection{Calcium content determination}

The amount of calcium present in calcium uridine monophosphate (CaUMP) sediment was measured with an Inductively Coupled Plasma - Atomic Emission Spectrometer (iCAP 9300 series, Thermo Electron). Five to ten grams of samples were weighed into a $100 \mathrm{~mL}$ flask, to which $10 \mathrm{~mL}$ of $25 \%$ acetic acid was added. Samples were placed in a $100{ }^{\circ} \mathrm{C}$ water bath for $90 \mathrm{~min}$, followed by cooling and adjusting the volume to $100 \mathrm{~mL}$ using demineralized water. Finally, the sample was pumped into the ICP-AES and measured on its emission rate. Calibration was done with standard calcium chloride solutions of 1 and $10 \mathrm{~g} \cdot \mathrm{L}^{-1}$.

\section{RESULTS AND DISCUSSION}

A solution of UMP molecules can hydrolyze into uridine and phosphate. This hydrolysis is temperature and $\mathrm{pH}$ dependent. The amount of hydrolysis was investigated between $\mathrm{pH} 2$ and 8 in $50 \mathrm{mmol} \cdot \mathrm{L}^{-1} \mathrm{CaCl}_{2}$ with $50 \mathrm{mmol} \cdot \mathrm{L}^{-1} \quad \mathrm{Na}_{2} \mathrm{UMP}$ solution (Fig. 2). These calcium and phosphate concentrations were selected, because the casein micelles in concentrated dairy products have comparable calcium concentrations.

Figures $2 \mathrm{a}$ and $2 \mathrm{~b}$ show that in acid conditions $\sim 10 \%$ of $\mathrm{Na}_{2} \mathrm{UMP}$ is hydrolyzed into uridine and phosphate. The $\mathrm{pH}$-dependent hydrolysis of $\mathrm{Na}_{2} \mathrm{UMP}$ is, however, negligible around pH $8.0(\sim 99 \%$ UMP and $1 \%$ uridine). Consequently, no free phosphate groups, able to interact with calcium ions, can be formed. Calciumphosphate interaction is, in this way, solely determined by UMP molecules.

The extent of calcium-phosphate interaction is $\mathrm{pH}$ dependent: none of calcium and phosphate ions are in complexes below pH 5.2 [34]. In Figure 3, results are shown for titration of sterilized $50 \mathrm{mmol} \cdot \mathrm{L}^{-1} \mathrm{CaCl}_{2}$ with $50 \mathrm{mmol} \cdot \mathrm{L}^{-1} \quad \mathrm{Na}_{2} \mathrm{UMP}$ solution at ambient temperature from $\mathrm{pH} 8.0$ to 5.0, while measuring the calcium-ion activity and turbidity.

This titration indicated that maximum interaction between calcium and UMP is obtained at $\mathrm{pH}$ 8.0. Around $\mathrm{pH} 6.0$ maximal calcium-ion activity and minimal turbidity were measured, indicating that calcium and UMP were not bound. For this reason, all samples were prepared at $\mathrm{pH} 8.0$, assuming that other phosphates will give maximal binding with calcium at $\mathrm{pH} 8.0$ as well.

Conductivity is often measured to analyze ion interactions. In our study, conductivities were determined as measure for the calcium-binding capacity. Theoretical conductivities were calculated using reported conductivities approaching infinite dilution, also named limiting conductivity $[8,11]$. Calculations were done for sodium, phosphate, calcium, chloride, hydrogen, and hydroxide ions by taking into account calcium phosphate binding and $\mathrm{pH}$. Conductivities were calculated at specific concentrations by using the expected reactivity of $3: 2$ with $\mathrm{Na}_{2} \mathrm{HPO}_{4}, 3: 1$ with SHMP, and 6:1 with SP; $\mathrm{Na}_{2}$ UMP did not react with all available calcium ions and for that reason conductivities were calculated using measured calcium-ion activities. No limiting conductivities were available for $\mathrm{Na}_{2} \mathrm{UMP}$, SHMP, and SP. Conductivities at phosphate concentration ranges of $0.5-40 \mathrm{mmol} \cdot \mathrm{L}^{-1}$ were therefore measured and plotted in conductivity-concentration curves. Extrapolation to infinite dilution 

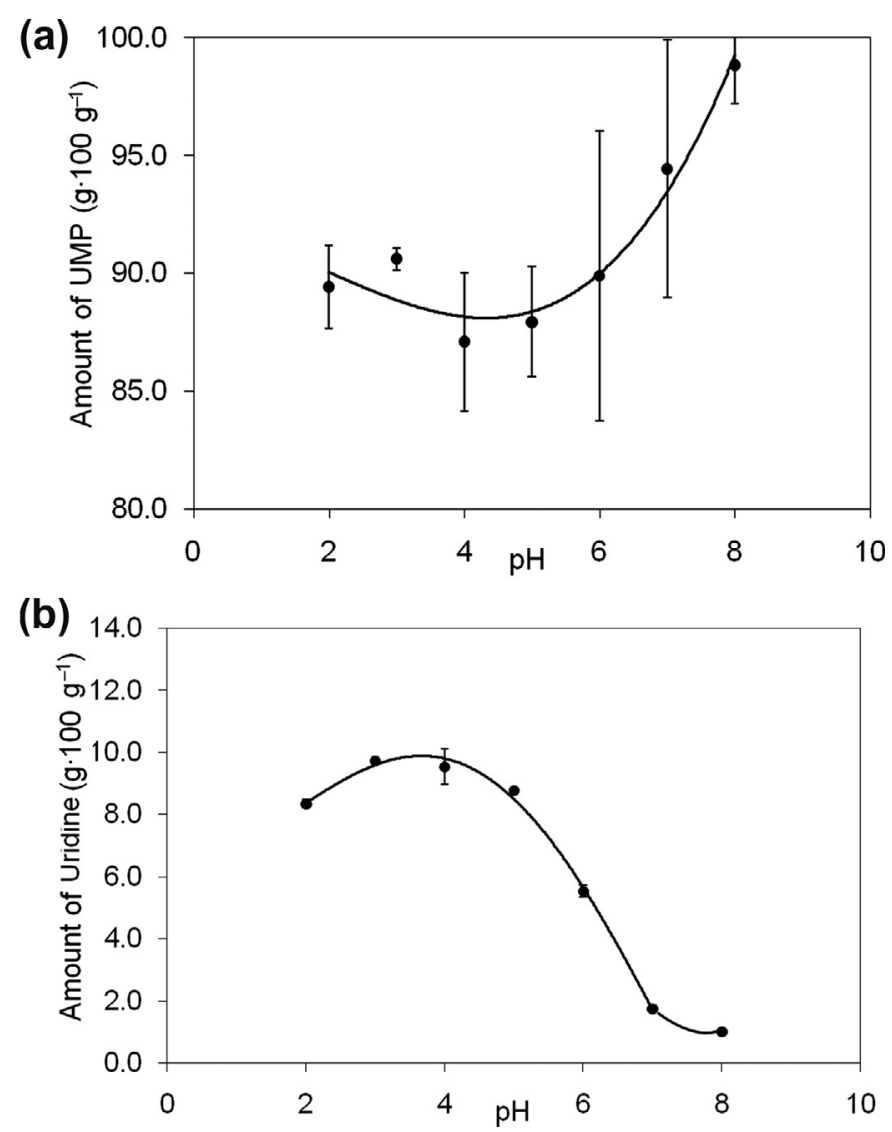

Figure 2. The $\mathrm{pH}$-dependent hydrolysis of $50 \mathrm{mmol} \cdot \mathrm{L}^{-1} \mathrm{Na}_{2} \mathrm{UMP}$ into uridine and free phosphate. (a) Amount of UMP after sterilization. (b) Amount of uridine after sterilization.

resulted in limiting conductivities of $0.108 \mathrm{mS} \cdot \mathrm{L} \cdot \mathrm{mmol}^{-1} \cdot \mathrm{cm}^{-1}$ for $\mathrm{Na}_{2} \mathrm{UMP}$, $0.282 \mathrm{mS} \cdot \mathrm{L} \cdot \mathrm{mmol}^{-1} \cdot \mathrm{cm}^{-1}$ for SHMP, $0.660 \mathrm{mS} \cdot \mathrm{L} \cdot \mathrm{mmol}^{-1} \cdot \mathrm{cm}^{-1}$ for $\mathrm{SP}$, and $0.164 \mathrm{mS} \cdot \mathrm{L} \cdot \mathrm{mmol}^{-1} \cdot \mathrm{cm}^{-1}$ for $\mathrm{Na}_{2} \mathrm{HPO}_{4}$. The latter value approximates the calculated conductivity of $0.166 \mathrm{mS} \cdot \mathrm{L} \cdot \mathrm{mmol}^{-1} \cdot \mathrm{cm}^{-1}$ obtained from the limiting conductivity of reported individual ionic species [8]. Experimental and calculated conductivities are depicted in Figure 4.

Conductivities were stable in $\mathrm{Na}_{2} \mathrm{UMP}$, $\mathrm{Na}_{2} \mathrm{HPO}_{4}$, and SP samples before and after heating, whereas increased conductivities were measured in SHMP samples after heating. This indicated calcium release from HMP during heating and negligible increase of calcium phosphate binding during sterilization. Slightly higher conductivities were calculated than measured, because conductivities calculated from limiting conductivities overestimate experimental conductivities [8]. The trends were comparable in the experimental and calculated conductivity curves. The minimum at $33.3 \mathrm{mmol} \cdot \mathrm{L}^{-1}$ in $\mathrm{Na}_{2} \mathrm{HPO}_{4}$ samples was also measured. The bends at $8.3 \mathrm{mmol} \cdot \mathrm{L}^{-1}$ in SHMP and $16.7 \mathrm{mmol} \cdot \mathrm{L}^{-1}$ in SP were not measured clearly. The bends in the curves illustrate the concentrations at which all 


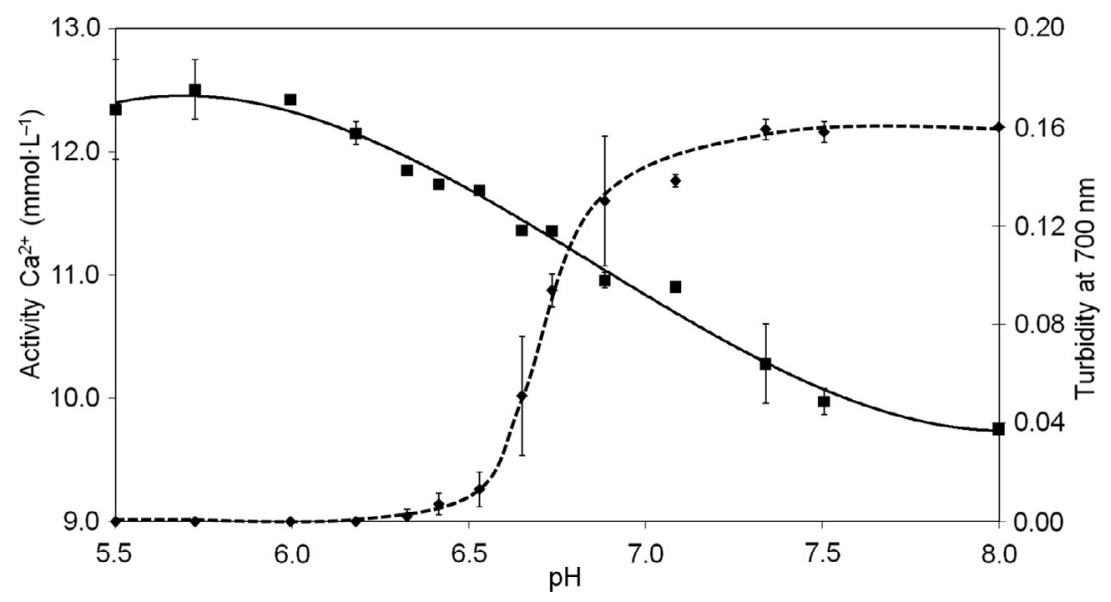

Figure 3. Calcium-ion activity and turbidity given as function of $\mathrm{pH}$ of heated $50 \mathrm{mmol} \cdot \mathrm{L}^{-1} \mathrm{CaCl}_{2}$ with $50 \mathrm{mmol} \cdot \mathrm{L}^{-1} \mathrm{Na}_{2} \mathrm{UMP}$ solution titrated from $\mathrm{pH} 8.0$ to 5.0 at ambient temperature with $1 \mathrm{~N}$ $\mathrm{HCl}$. (匹) Calcium-ion activity and (- - - -) turbidity.

available calcium had reacted with the specific phosphate. Overall, the conductivity method was not sensitive and specific enough to determine the calcium-binding capacity of phosphates, as all species contribute to the conductivity. The calcium-ion activity method, however, specifically measures activity of calcium ions and can give useful information about the binding of calcium with these phosphates.

Experimental calcium-ion activities were compared with calculated curves of the phosphates (Fig. 5). We calculated the calciumion activities $\left(a_{\mathrm{Ca}^{2+}}\right)$ with the formula of Davies [3], that is based on the equation of Debye-Hückel, but is extended with a term that is proportional to the ionic strength of the solution and accounts for solvability and short-range interactions of ions. The Debye-Hückel equation is valid for ionic strengths up to $10 \mathrm{mmol} \cdot \mathrm{L}^{-1}$, whereas the Davies equation can be applied for ionic strength of up to $500 \mathrm{mmol} \cdot \mathrm{L}^{-1}[3,11,24]$. Figure 5 shows that the calculated calciumion activity of $17 \mathrm{mmol} \cdot \mathrm{L}^{-1}$ (Fig. 5b) corresponds to the experimentally determined activity of $a_{\mathrm{Ca}^{2+}}=18 \pm 1 \mathrm{mmol} \cdot \mathrm{L}^{-1}$
(Fig. 5a) for $50 \mathrm{mmol} \cdot \mathrm{L}^{-1} \mathrm{CaCl}_{2}$ solution with $0 \mathrm{mmol} \cdot \mathrm{L}^{-1}$ phosphate.

The calculated calcium-ion activities of $\mathrm{Na}_{2} \mathrm{HPO}_{4}$, SHMP, and SP were consistent with the experimental calcium-ion activities, showing calcium-binding capacity of $3: 2$ for $\mathrm{Na}_{2} \mathrm{HPO}_{4}, 3: 1$ for SHMP, and 6:1 for SP before and after sterilization. Using the Davies equation we calculated calcium-ion activities of zero for $33.3 \mathrm{mmol} \cdot \mathrm{L}^{-1}$ $\mathrm{Na}_{2} \mathrm{HPO}_{4}, \quad 16.7 \mathrm{mmol} \cdot \mathrm{L}^{-1}$ SHMP, and $8.3 \mathrm{mmol} \cdot \mathrm{L}^{-1} \mathrm{SP}$. The experimental calcium-ion activities approached zero values around these concentrations as well. $\mathrm{Na}_{2} \mathrm{HPO}_{4}$ can react with calcium in a ratio of $1: 1$ or $3: 2$ to form $\mathrm{CaHPO}_{4}$ or $\mathrm{Ca}_{3}\left(\mathrm{PO}_{4}\right)_{2}$ complexes $[22,30]$. Figures $5 \mathrm{a}$ and $5 \mathrm{~b}$ confirm that $\mathrm{Ca}_{3}\left(\mathrm{PO}_{4}\right)_{2}$ complexes are dominant in $50 \mathrm{mmol} \cdot \mathrm{L}^{-1} \mathrm{CaCl}_{2}$ solution at $\mathrm{pH} 8.0$. The calculated $\mathrm{Na}_{2} \mathrm{UMP}$ curve depicts binding of 1:1 between calcium and UMP. However, compared to Figures $5 \mathrm{a}$ and $5 \mathrm{~b}$, $\mathrm{Na}_{2} \mathrm{UMP}$ does not react with all available calcium ions: $\mathrm{Na}_{2} \mathrm{UMP}$ has a lower equilibrium binding constant to calcium than the other phosphates. As a result, the calculated and experimental calcium-ion activity curves 


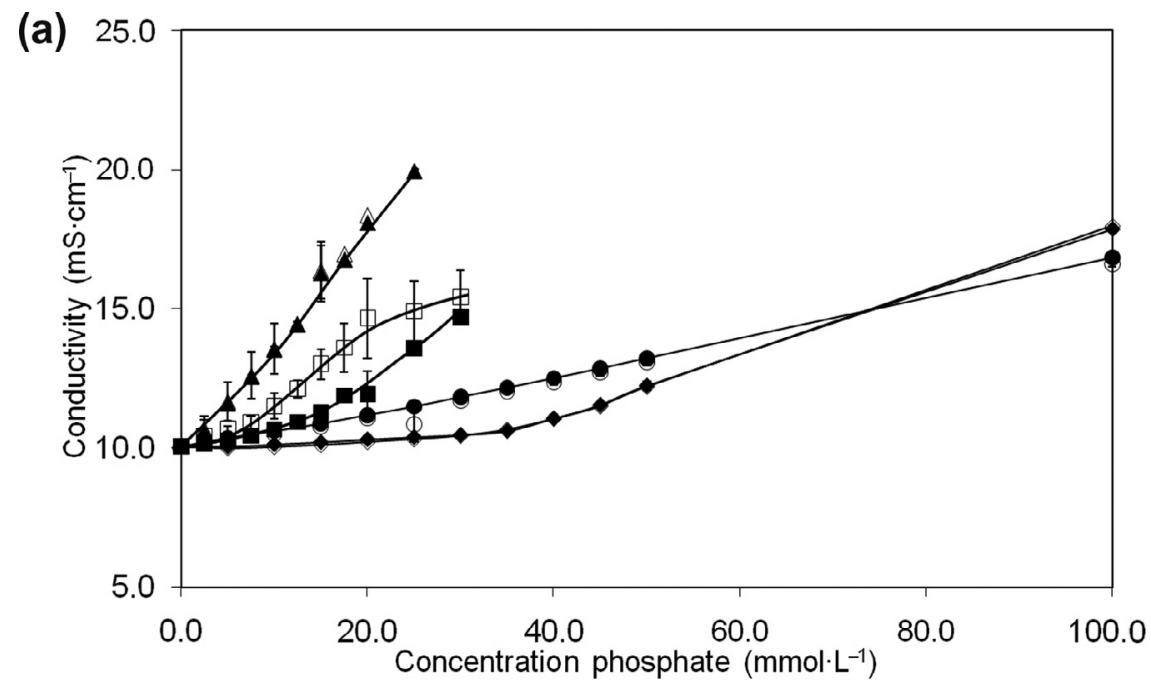

(b)

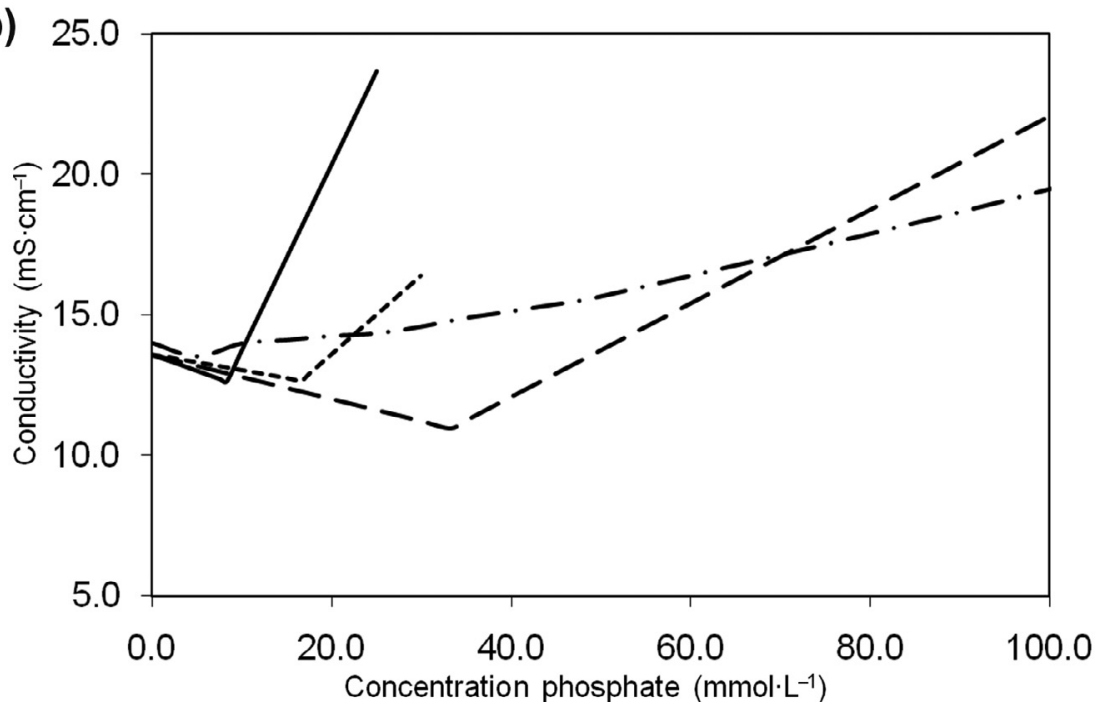

Figure 4. Experimental (a) and calculated (b) conductivity of phosphates in $50 \mathrm{mmol} \cdot \mathrm{L}^{-1} \mathrm{CaCl}_{2}$ solution. •, $\mathrm{Na}_{2} \mathrm{UMP}$ before heating; $\circ, \mathrm{Na}_{2} \mathrm{UMP}$ after heating; $\mathrm{Na}_{2} \mathrm{HPO}_{4}$ before heating; $\diamond, \mathrm{Na}_{2} \mathrm{HPO}_{4}$ after heating; $\mathbf{m}$ SHMP before heating; $\square$, SHMP after heating; $\mathbf{\Delta}$, SP before heating; $\Delta$, SP after heating; ---, $\mathrm{Na}_{2} \mathrm{UMP} ;-\ldots, \mathrm{Na}_{2} \mathrm{HPO}_{4} ;-\cdots,-.-$ SHMP; — - SP.

of $\mathrm{Na}_{2} \mathrm{UMP}$ were different. Moreover, its calcium-binding capacity is not similar to the binding of calcium to $\mathrm{Na}_{2} \mathrm{HPO}_{4}$ for two reasons. First of all, the third proton in $\mathrm{Na}_{2} \mathrm{UMP}$ is not easily released from the uracil ring, which is due to the mesomeric ring and $\mathrm{pH}$. The proton will only be released above $\mathrm{pH} \quad 10 \quad\left(\mathrm{pKa}_{3}\right.$ is 9.5) and calcium will not be bound to uracil $[25,26]$. Consequently, around neutral $\mathrm{pH}$, 

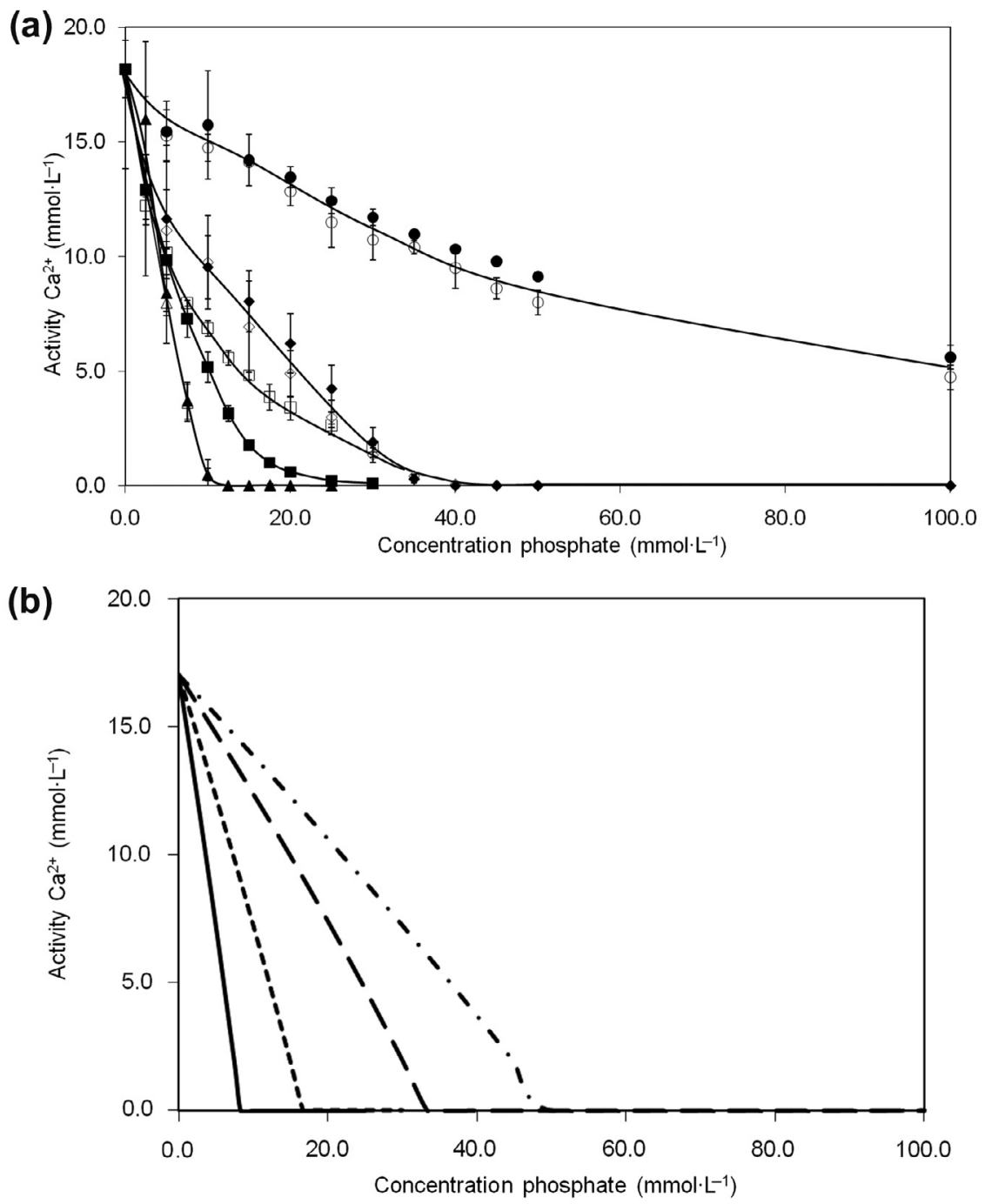

Figure 5. Experimental (a) and calculated (b) calcium-ion activity of phosphates in $50 \mathrm{mmol} \cdot \mathrm{L}^{-1}$ $\mathrm{CaCl}_{2}$ solution. $\bullet, \mathrm{Na}_{2} \mathrm{UMP}$ before heating; $\odot, \mathrm{Na}_{2} \mathrm{UMP}$ after heating; $\bullet \mathrm{Na}_{2} \mathrm{HPO}_{4}$ before heating; $\diamond, \mathrm{Na}_{2} \mathrm{HPO}_{4}$ after heating; $\mathbf{n}, \mathrm{SHMP}$ before heating; $\square$, SHMP after heating; $\mathbf{\wedge}$, SP before heating; $\Delta$, SP after heating; ---, $\mathrm{Na}_{2} \mathrm{UMP} ;-\ldots, \mathrm{Na}_{2} \mathrm{HPO}_{4} ;---\cdot-$, SHMP; —, SP, resulting in CaUMP, $\mathrm{Ca}_{3}(\mathrm{PO} 4)_{2}, \mathrm{Ca}_{3}\left(\mathrm{PO}_{3}\right)_{6}$, and $\mathrm{Ca}_{6}$ phytate, respectively.

a calcium-binding capacity of $1: 1$ is expected rather than 3:2 for UMP. Secondly, although the phosphate residue of the nucleotide largely determines the stability of cationUMP complexes, the nucleobase is responsible for the selectivity or specificity of these 


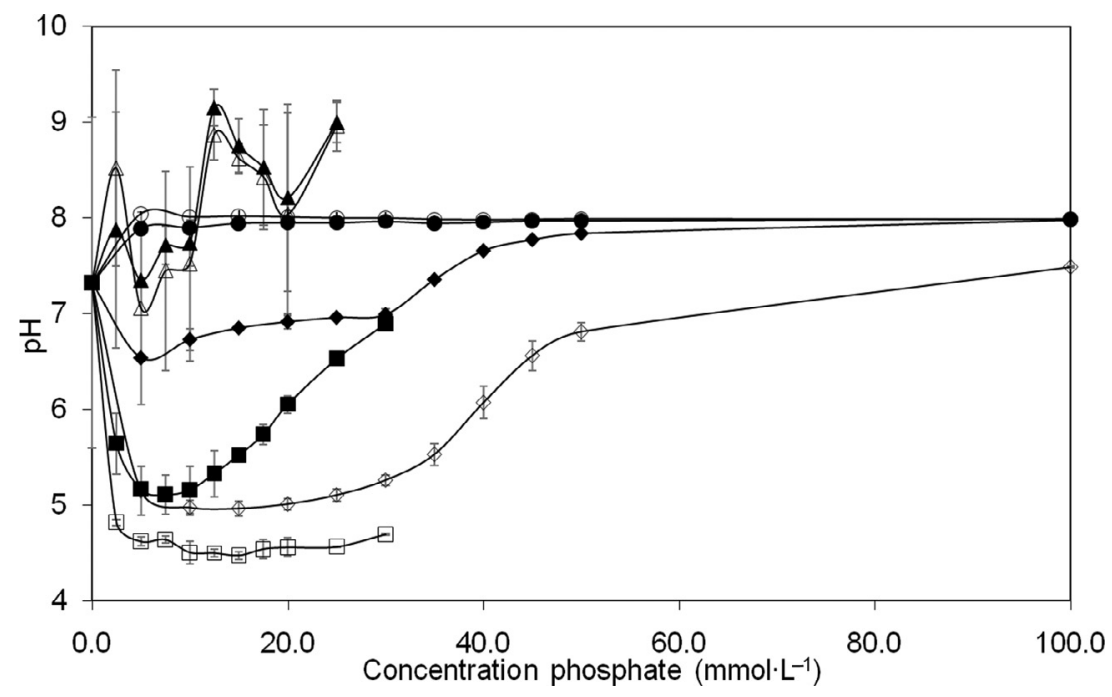

Figure 6. The $\mathrm{pH}$ of phosphates in $50 \mathrm{mmol} \cdot \mathrm{L}^{-1} \mathrm{CaCl}_{2}$ solution. $\bullet, \mathrm{Na}_{2} \mathrm{UMP}$ before heating; $\circ, \mathrm{Na}_{2} \mathrm{UMP}$ after heating; $\bullet \mathrm{Na}_{2} \mathrm{HPO}_{4}$ before heating; $\diamond, \mathrm{Na}_{2} \mathrm{HPO}_{4}$ after heating; $\mathbf{-}$ SHMP before heating; $\square$, SHMP after heating; $\Delta$, SP before heating; $\Delta$, SP after heating.

complexes by hydrogen binding and cation coordination $[25,26]$. As a consequence, UMP has a lower affinity for calcium ions than the other phosphates, and free calcium and free phosphate can exist simultaneously in solution. The equilibrium constant and the calcium-binding capacity of $\mathrm{Na}_{2} \mathrm{UMP}$ are calculated in the last section of this study.

In SHMP samples, an increased calciumion activity was observed after sterilization, as a result of sterilization and $\mathrm{pH}$ decline. The $\mathrm{pH}$ decline was larger during sterilization, because of calcium binding and proton release from HMP at the same time. Final $\mathrm{pH}$ values in the samples before and after sterilization are depicted in Figure 6. Furthermore, calcium binding could be reduced because of SHMP hydrolysis into sodium trimetaphosphate and sodium orthophosphate under acidic conditions [31]. For example, Gaucheron and Walstra [4, 34] stated that below $\mathrm{pH}$ 5.2, calcium phosphate bindings are less stable and below $\mathrm{pH} 3.5$, no calcium phosphate binding was present anymore in aqueous solution. As SHMP samples remained above $\mathrm{pH} 5.2$ before heating, all calcium ions should be bound to SHMP. However, after heating, the $\mathrm{pH}$ decreased to $\mathrm{pH} 4.2$ and a part of the calcium ions, as shown in Figure 5a, were released from SHMP.

Vujicic et al. [32] reported that addition of alkaline earth ions to polyphosphates like tetra- or hexametaphosphate causes release of sodium and protons bound to these polyphosphates as evidenced by the $\mathrm{pH}$ drop. The total binding between cations and phosphates depends on the amount of cations added and the amount of available binding sites on phosphates [32]. Consequently, the largest $\mathrm{pH}$ drop was expected with SHMP and SP followed by $\mathrm{Na}_{2} \mathrm{HPO}_{4}$. A pH drop was observed in SHMP samples, but not in SP samples. A larger $\mathrm{pH}$ drop was observed in $\mathrm{Na}_{2} \mathrm{HPO}_{4}$ samples in comparison with SP samples. Large fluctuations in SP samples were caused by a weak buffering capacity of $\mathrm{SP}$ around $\mathrm{pH} \quad 8.0$ $\left(\mathrm{pKa}_{7}, \mathrm{pKa}_{8}\right.$, and $\mathrm{pKa}_{9}$ are 5.7, 6.9, and 

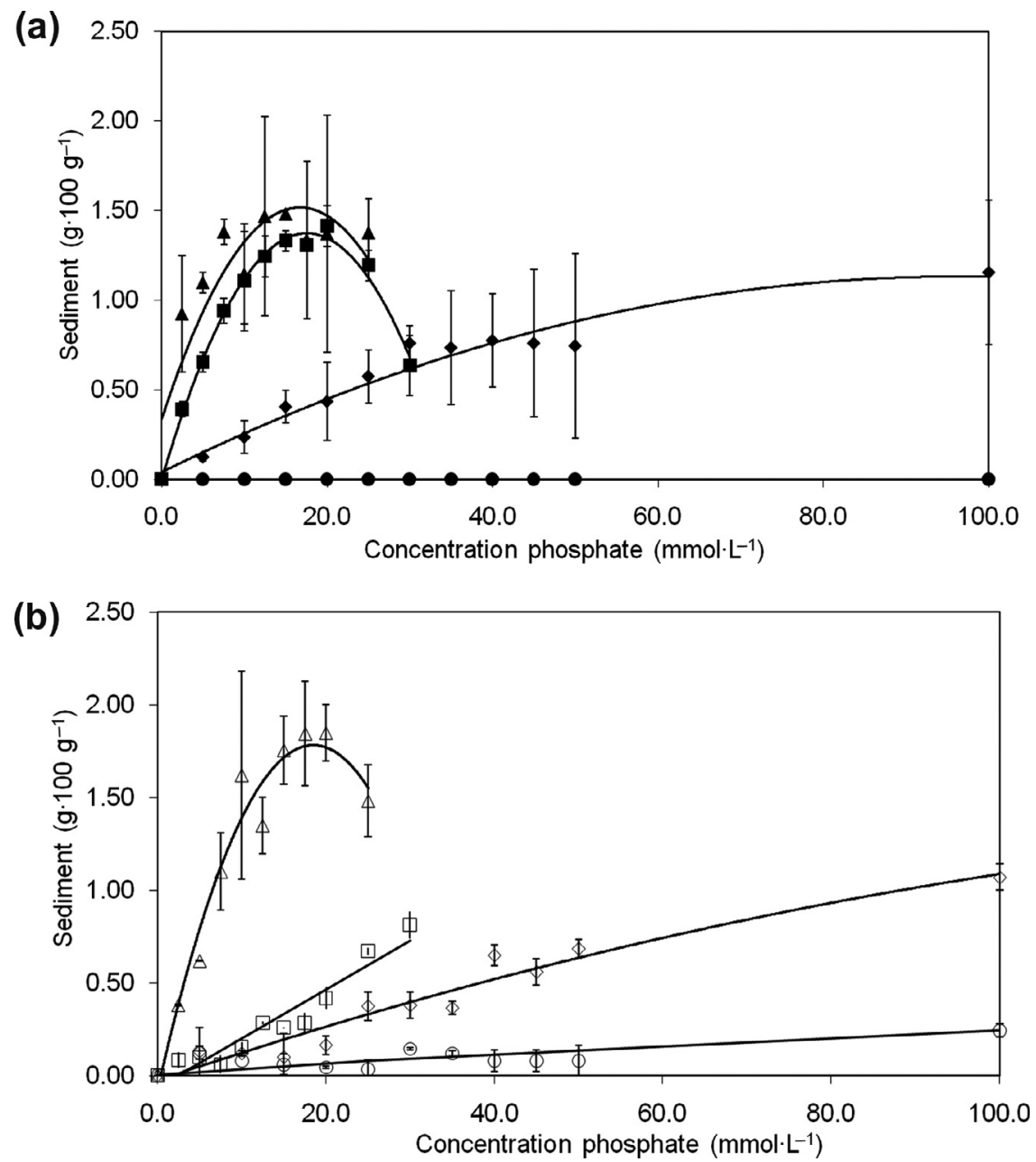

Figure 7. Experimental sediment of phosphates in $50 \mathrm{mmol} \cdot \mathrm{L}^{-1} \mathrm{CaCl}_{2}$ solution before (a) and after heating (b). •, $\mathrm{Na}_{2} \mathrm{UMP}$ before heating; $\mathrm{Na}_{2} \mathrm{HPO}_{4}$ before heating; $\square$, SHMP before heating; $\Delta$, SP before heating; $\odot, \mathrm{Na}_{2} \mathrm{UMP}$ after heating; $\diamond, \mathrm{Na}_{2} \mathrm{HPO}_{4}$ after heating; $\square$, SHMP after heating; $\Delta$, SP after heating.

7.6, respectively) [28]. Calcium-ion activity results of the $\mathrm{Na}_{2} \mathrm{HPO}_{4}$ trial showed that $\mathrm{Ca}_{3}\left(\mathrm{PO}_{4}\right)_{2}$ was formed. Around $\mathrm{pH}$ 8.0 , one or two protons had to be released to form $\mathrm{Ca}_{3}\left(\mathrm{PO}_{4}\right)_{2}\left(\mathrm{pKa}_{2}\right.$ is 7.2$)$ and this resulted in a $\mathrm{pH}$ decrease. In case of $\mathrm{Na}_{2} \mathrm{UMP}$, a third proton could not be released from uracil and the $\mathrm{pH}$ remained at 8.0 in all $\mathrm{Na}_{2} \mathrm{UMP}$ samples.

The amount of sediment and turbidity was measured before and after heating of all phosphates to confirm their calciumbinding capacity. Results are shown in Figures 7 and 8 . 

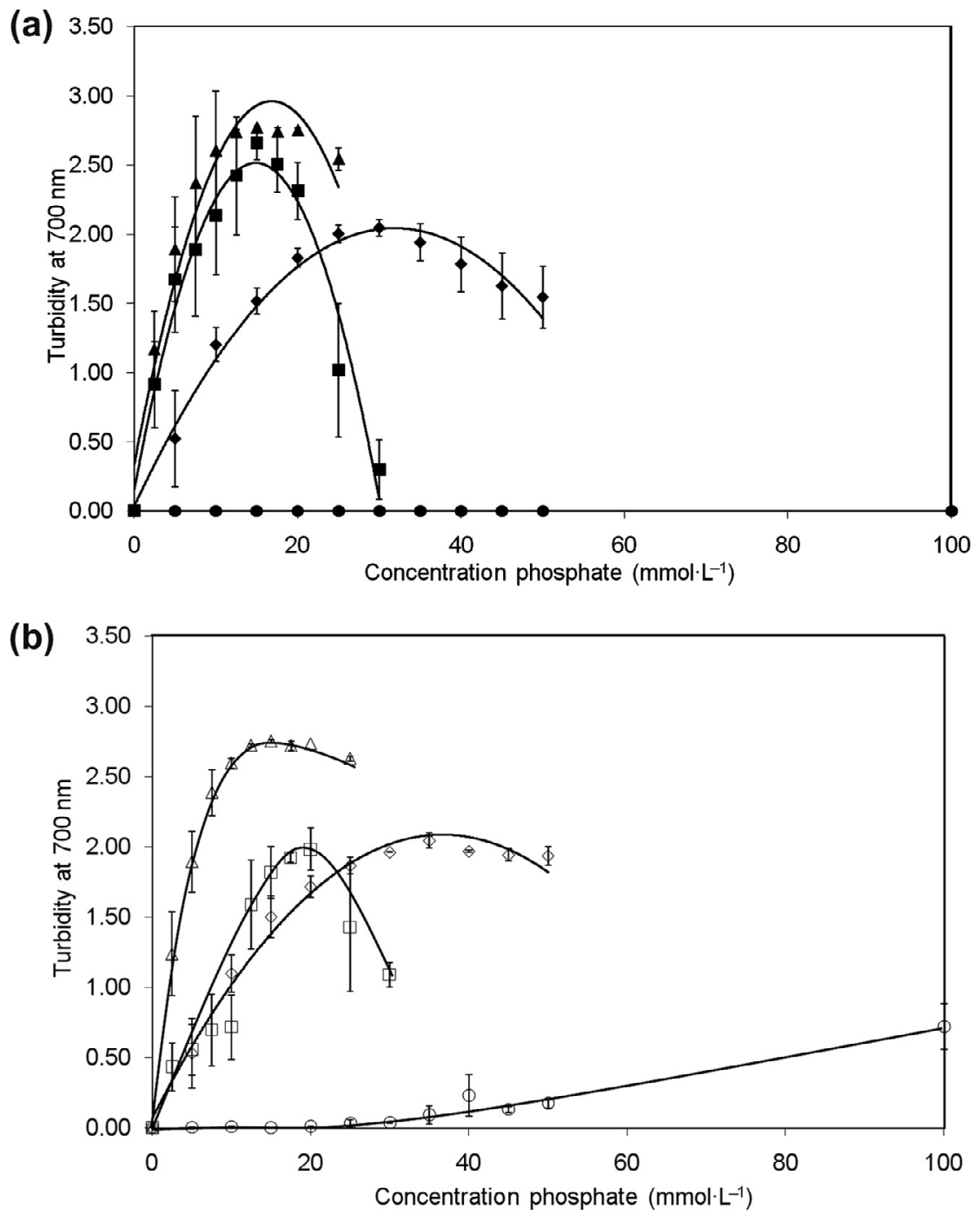

Figure 8. Turbidity at $700 \mathrm{~nm}$ of phosphates in $50 \mathrm{mmol} \cdot \mathrm{L}^{-1} \mathrm{CaCl}_{2}$ solution before (a) and after heating (b). •, $\mathrm{Na}_{2} \mathrm{UMP}$ before heating; $\mathrm{Na}_{2} \mathrm{HPO}_{4}$ before heating; $\mathbf{}$, SHMP before heating; $\Delta$, SP before heating; $\odot, \mathrm{Na}_{2} \mathrm{UMP}$ after heating; $\diamond, \mathrm{Na}_{2} \mathrm{HPO}_{4}$ after heating; $\square$, SHMP after heating; $\Delta$, SP after heating.

Figures 7 and 8 showed that the same trends were obtained with measuring the amount of sediment and turbidity. Before heating no precipitation appeared in $\mathrm{Na}_{2} \mathrm{UMP}$ samples, whereas after sterilization an increase in sediment and turbidity was measured. As similar calcium-ion activities were measured before and after sterilization, we concluded that CaUMP complexes are soluble, but precipitate during sterilization. Theoretical sediment amounts were calculated for $\mathrm{Ca}_{3}\left(\mathrm{PO}_{4}\right)_{2}$ 


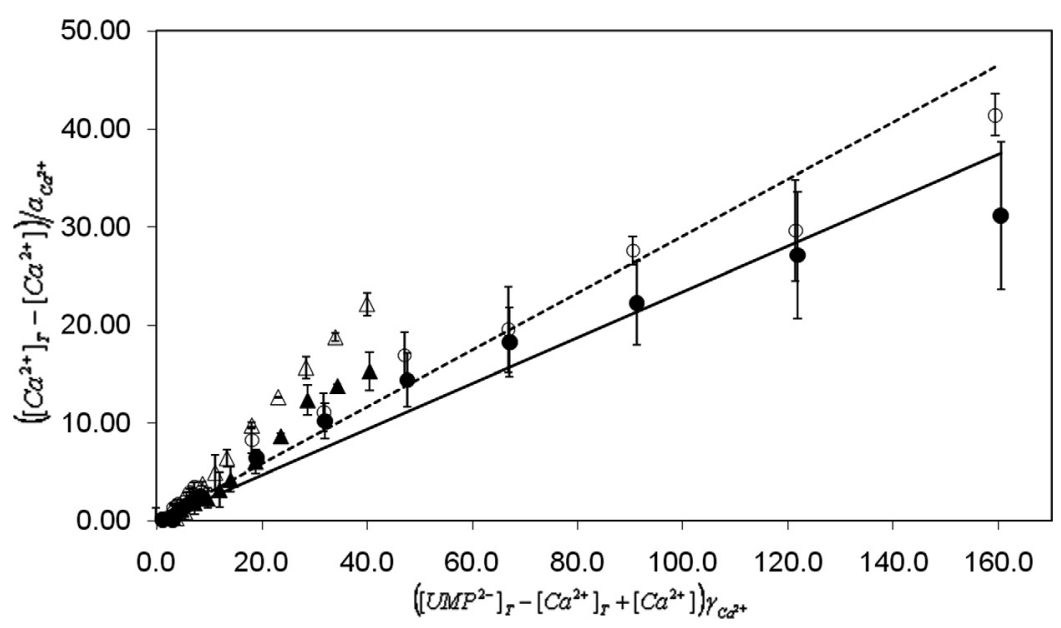

Figure 9. Model fits with $n=1$ and $m=1$ to determine $K_{\text {CaUMP }}$ before (-) and after (---) heating. $\Delta, 20 \mathrm{mmol} \cdot \mathrm{L}^{-1} \mathrm{CaCl}_{2}$ with $0-160 \mathrm{mmol} \cdot \mathrm{L}^{-1} \mathrm{Na}_{2} \mathrm{UMP}$ before heating; $\Delta, 20 \mathrm{mmol} \cdot \mathrm{L}^{-1} \mathrm{CaCl}_{2}$ with 0-160 mmol $\cdot \mathrm{L}^{-1} \mathrm{Na}_{2} \mathrm{UMP}$ after heating; $\bullet, 50 \mathrm{mmol} \cdot \mathrm{L}^{-1} \mathrm{CaCl}_{2}$ with $0-400 \mathrm{mmol} \cdot \mathrm{L}^{-1} \mathrm{Na}_{2} \mathrm{UMP}$ before heating; $\circ$, $50 \mathrm{mmol} \cdot \mathrm{L}^{-1} \mathrm{CaCl}_{2}$ with $0-400 \mathrm{mmol} \cdot \mathrm{L}^{-1} \mathrm{Na}_{2} \mathrm{UMP}$ after heating.

from $\mathrm{Na}_{2} \mathrm{HPO}_{4}, \mathrm{Ca}_{3} \mathrm{HMP}$ from SHMP, and $\mathrm{Ca}_{6}$ phytate from SP. For $\mathrm{Na}_{2} \mathrm{UMP}$, the values could only be calculated by using equilibrium constant $K_{\mathrm{CaUMP}}$, because $\mathrm{Na}_{2} \mathrm{UMP}$ did not react with all available calcium ions. The calculated sediment was similar to the experimental sediment before heating. In the heated samples, however, less sediment was present due to the $\mathrm{pH}$ drop during sterilization, resulting in the release of calcium phosphate bindings. Although large standard deviations were found with sediment analyses, the results confirmed the reactivity with calcium ions of $3: 2$ for $\mathrm{Na}_{2} \mathrm{HPO}_{4}, 3: 1$ for SHMP, and 6:1 for SP. The large standard deviations can be explained by low accuracy of sediment determination and by potential inclusion of crystal water during drying.

Above $16.7 \mathrm{mmol} \cdot \mathrm{L}^{-1}$ SHMP and $8.3 \mathrm{mmol} \cdot \mathrm{L}^{-1} \mathrm{SP}$, a decrease in both sedimentation and turbidity was observed. An excess of phosphates was present above these concentrations and an equilibrium exchange between already bound calcium and over-dosed phosphates occurred which, consequently, decreased sediment and turbidity. $\mathrm{Na}_{2} \mathrm{HPO}_{4}$ is a weaker chelator than SHMP and SP and has a weaker effect on calcium release than SHMP and SP.

$\mathrm{Na}_{2} \mathrm{HPO}_{4}$, SHMP, and SP react, depending on their concentration and $\mathrm{pH}$, with all available calcium ions and therefore have high equilibrium binding constants. Our results showed that $\mathrm{Na}_{2} \mathrm{UMP}$ has lower affinity for calcium ions than $\mathrm{Na}_{2} \mathrm{HPO}_{4}$, SHMP, and SP, and as a consequence the calcium-binding capacity of UMP could not be determined directly. Free calcium, UMP, and CaUMP are in equilibrium in aqueous solution. The equilibrium constant $K_{\text {CaUMP }}$ was calculated with results obtained from experimental calcium-ion activities. Concentration ranges of $0-160$ and 0-400 $\mathrm{mmol} \cdot \mathrm{L}^{-1} \mathrm{Na}_{2} \mathrm{UMP}$ in solutions of 20 and $50 \mathrm{mmol} \cdot \mathrm{L}^{-1} \mathrm{CaCl}_{2}$, respectively, were analyzed for their calcium-ion activity before and after heating. Results were plotted in a linear relation to calculate the calcium-binding capacity and equilibrium constant of CaUMP (Fig. 9). The deduction of this linear relation is described in the Appendix. 
An equilibrium constant $\left(K_{\mathrm{CaUMP}}\right)$ was determined to be $0.26 \pm 0.06 \mathrm{~L} \cdot \mathrm{mol}^{-1}$ before heating and $0.32 \pm 0.09 \mathrm{~L} \cdot \mathrm{mol}^{-1}$ after heating. This resulted in an average equilibrium constant $K_{\text {CaUMP }}$ of $0.29 \pm$ $0.08 \mathrm{~L} \cdot \mathrm{mol}^{-1}$. Furthermore, linear fits were obtained with $n=1$ and $m=1$ indicating a calcium-binding ratio of $1: 1$ for UMP. No linear fits were obtained with other binding ratios between calcium and UMP. This best fitted binding ratio of 1:1 was in the line of expectation, because UMP has $\mathrm{pKa}$ values of $\mathrm{pKa}_{1}$ 0.7-1.0, $\mathrm{pKa}_{2}$ 5.6-6.2, and $\mathrm{pKa}_{3}$ 9.5-10.0 [2, 9, 10, 13, 23] and thus is mainly in the divalent anionic form at $\mathrm{pH}$ 8.0. Moreover, analysis of the CaUMP sediment confirmed that equal amounts of calcium and UMP were present.

This study has shown that $\mathrm{Na}_{2} \mathrm{HPO}_{4}$, SHMP, and SP have a strong calciumbinding capacity. They are useful additives in the dairy industry to reduce calcium aggregation during processing or shelf life of, for example, calcium-enriched milk, evaporated milk, or medical nutrition. $\mathrm{Na}_{2} \mathrm{UMP}$ is a nutritional additive, which has less influence on the (heat) stability of dairy products.

\section{CONCLUSIONS}

The calcium-ion activity results showed that calcium reacts with $\mathrm{Na}_{2} \mathrm{HPO}_{4}$ in a ratio of $3: 2$ to $\mathrm{Ca}_{3}\left(\mathrm{PO}_{4}\right)_{2}$, with SHMP in a ratio of $3: 1$ to $\mathrm{Ca}_{3}\left(\mathrm{PO}_{3}\right)_{6}$, and with $\mathrm{SP}$ in a ratio of $6: 1$ to $\mathrm{Ca}_{6}$ phytate in a $50 \mathrm{mmol} \cdot \mathrm{L}^{-1}$ $\mathrm{CaCl}_{2}$ solution at $\mathrm{pH}$ 8.0. Measuring calcium-ion activity was more sensitive and specific for determining reaction ratios than measuring conductivity. Sediment and turbidity analyses elucidated that these three phosphates formed insoluble complexes with calcium. $\mathrm{Na}_{2} \mathrm{UMP}$ reacted to a lesser extent with calcium ions than the other phosphates: CaUMP complexes were in equilibrium with free calcium and UMP at $\mathrm{pH}$ 8.0. These CaUMP complexes were soluble before sterilization and insoluble after sterilization. The hydrolysis of $\mathrm{Na}_{2} \mathrm{UMP}$ into uridine and phosphate was negligible, whereas hydrolysis increased with decreasing $\mathrm{pH}$. An average $K_{\mathrm{CaUMP}}$ of $0.29 \pm 0.08 \mathrm{~L} \cdot \mathrm{mol}^{-1}$ was determined with a calcium-binding capacity of $1: 1$ for UMP. Analysis of the CaUMP sediment confirmed a calcium-binding capacity of $1: 1$. The structure of phosphate molecules determined their calcium-binding capacity rather than organic or inorganic origin of phosphates. Polyphosphates were stronger chelators than orthophosphates. Overall, this study has elucidated the calcium-binding capacity of these phosphates, which is useful information to understand the interaction of calcium, phosphate, and casein micelles for the development of, for example, medical nutrition.

\section{APPENDIX}

Free calcium, UMP, and CaUMP are in equilibrium in aqueous solution according to:

$$
n \mathrm{Ca}^{2+}+m \mathrm{UMP}^{2-} \rightleftarrows \mathrm{Ca}_{n} \mathrm{UMP}_{m} .
$$

The equilibrium constant $K_{\mathrm{CaUMP}}$ can be calculated indirectly from experimental calcium-ion activities and conservations of calcium and UMP, and is related to the activities of the different species according to:

$$
\begin{gathered}
K=\frac{a_{\mathrm{Ca}_{n} \mathrm{UMP}_{m}}}{\left(a_{\mathrm{Ca}^{2+}}\right)^{n}\left(a_{\mathrm{UMP}^{2-}}\right)^{m}} \\
{\left[\mathrm{Ca}^{2+}\right]_{\mathrm{T}}=\left[\mathrm{Ca}^{2+}\right]+\frac{1}{n}\left[\mathrm{Ca}_{n} \mathrm{UMP}_{m}\right]} \\
{\left[\mathrm{UMP}^{2-}\right]_{\mathrm{T}}} \\
=\left[\mathrm{UMP}^{2-}\right]+\frac{1}{m}\left[\mathrm{Ca}_{n} \mathrm{UMP}_{m}\right]
\end{gathered}
$$

where $\left[\mathrm{Ca}^{2+}\right]_{\mathrm{T}}$ is the total calcium concentration $\left(\mathrm{mmol} \cdot \mathrm{L}^{-1}\right),\left[\mathrm{Ca}^{2+}\right]$ is the 
experimental calcium ion concentration $\left(\mathrm{mmol} \cdot \mathrm{L}^{-1}\right), a_{\mathrm{Ca}^{2+}}$ is the calcium-ion activity $\left(\mathrm{mmol} \cdot \mathrm{L}^{-1}\right),\left[\mathrm{UMP}^{2-}\right]_{\mathrm{T}}$ is the added UMP concentration $\left(\mathrm{mmol} \cdot \mathrm{L}^{-1}\right)$, and $n$ and $m$ are the binding ratio for calcium and UMP, respectively.

Combination of equations (2)-(4), and realizing that concentrations can be converted into activities by multiplying with the activity coefficient $\gamma$, results in:

$$
K=\frac{\left(\left(\left[\mathrm{Ca}^{2+}\right]_{\mathrm{T}}-\left[\mathrm{Ca}^{2+}\right]\right) \gamma_{\mathrm{Ca}_{n} \mathrm{UMP}_{m}}\right) /\left(a_{\mathrm{Ca}^{2+}}\right)^{n}}{\left(\left(\left[\mathrm{UMP}^{2-}\right]_{\mathrm{T}}-\frac{n}{m}\left(\left[\mathrm{Ca}^{2+}\right]_{\mathrm{T}}-\left[\mathrm{Ca}^{2+}\right]\right)\right) \gamma_{\mathrm{Ca}^{2+}}\right)^{m}} .
$$

If the numerator is plotted against the denominator, a straight line is obtained with slope $K$.

If $n$ equals $m$, the activity coefficient $\gamma_{\text {CaUMP }}$ of the complex is equal to 1 and the equation simplifies to:

$$
K=\frac{\left(\left[\mathrm{Ca}^{2+}\right]_{\mathrm{T}}-\left[\mathrm{Ca}^{2+}\right]\right) / a_{\mathrm{Ca}^{2+}}}{\left(\left[\mathrm{UMP}^{2-}\right]_{\mathrm{T}}-\left[\mathrm{Ca}^{2+}\right]_{\mathrm{T}}+\left[\mathrm{Ca}^{2+}\right]\right) \gamma_{\mathrm{Ca}^{2+}}} .
$$

\section{REFERENCES}

[1] Csapo J., The influence of proteins on the solubility of calcium phosphate, J. Biol. Chem. 75 (1927) 509-515.

[2] Da Costa C.P., Okruszek A., Sigel H., Complex formation of divalent metal ions with uridine $5^{\prime}$-O-thiomonophosphate or methyl thiophosphate: comparison of complex stabilities with those of the parent phosphate ligands, ChemBioChem 4 (2003) 593-602.

[3] Davies C.W., Ion Association, Butterworths, London, UK, 1962.

[4] Gaucheron F., The minerals of milk, Reprod. Nutr. Dev. 45 (2005) 473-483.

[5] Hurrell R.F., Influence of vegetable protein sources on trace element and mineral bioavailability, J. Nutr. 133 (2003) 2973-2977.

[6] Kies A.K., Jonge de L.H., Kemme P.A., Jongbloed A.W., Interaction between protein, phytate, and microbial phytase. In vitro studies, J. Agric. Food Chem. 54 (2006) 1753-1758.

[7] Klevichis C., Grisham C.M., Phosphatemetal ion interactions of nucleotides and polynucleotides, Met. Ions Biol. Syst. 32 (1996) 1-26.

[8] Lide D.R., Handbook of Chemistry and Physics, CRC press, New York, USA, 1997.

[9] Lomozik L., Jastrzab R., Non-covalent and coordination interactions in $\mathrm{Cu}$ (II) systems with uridine, uridine 5'-monophosphate, and triamine or tetramine as biogenic amine analogues in aqueous solutions, J. Inorg. Biochem. 97 (2003) 179-190.

[10] Lomozik L., Jastrzab R., Copper(II) complexes with uridine, uridine 5'-monophosphate, spermidine, or spermine in aqueous solution, J. Inorg. Biochem. 93 (2003) 132-140.

[11] Lyklema J., Fundamentals of interface and colloid science. Volume I: Fundamentals, Academic press Ltd., London, UK, 1995.

[12] Martin C.J., Evans W.J., Phytic acid-metal ion interactions. II. The effect of $\mathrm{pH}$ on $\mathrm{Ca}$ (II) binding, J. Inorg. Biochem. 27 (1986) 17-30.

[13] Massoud S.S., Sigel H., Metal ion coordinating properties of pyrimidine-nucleoside 5'-monophosphate (CMP, UMP, TMP) and of simple phosphate monoesters, including D-ribose 5'-monophosphate. Establishment of relations between complex stability and phosphate basicity, Inorg. Chem. 27 (1988) 1447-1453.

[14] Mizuno R., Lucey J.A., Effects of emulsifying salts on the turbidity and calciumphosphate-protein interactions in casein micelles, J. Dairy Sci. 88 (2005) 3070-3078.

[15] Odagiri S., Nickerson T.A., Complexing of calcium by hexametaphosphate, oxalate, citrate, and EDTA in milk. I. Effects of complexing agents of turbidity and rennet coagulation, J. Dairy Sci. 47 (1964) 1306-1309.

[16] Odagiri S., Nickerson T.A., Chain length determination of polyphosphates, J. Dairy Sci. 47 (1964) 920-921.

[17] Odagiri S., Nickerson T.A., Complexing of calcium by hexametaphosphate oxalate, citrate and ethylenediamine-tetraacetate in milk. II. Dialysis of milk containing complexing agents, J. Dairy Sci. 48 (1965) 19-22. 
[18] Panouillé M., Nicolai T., Durand D., Heat induced aggregation and gelation of casein submicelles, Int. Dairy J. 14 (2004) 297-303.

[19] Perrin C., Meyer L., Mujahid C., Blake C.J., The analysis of $5^{\prime}$-nucleotides in infant formulae by HPLC, Food Chem. 74 (2001) 245-253.

[20] Philippe M., Le Graet Y., Gaucheron F., The effects of different cations on the physicochemical characteristics of casein micelles, Food Chem. 90 (2005) 673-683.

[21] Ping Zhang Z., Aoki T., Behaviour of calcium and phosphate in bovine casein micelles, Int. Dairy J. 6 (1996) 769-780.

[22] Pyne H.T., The colloidal phosphate of milk, Biochem. J. 28 (1934) 940-948.

[23] Saha A., Saha N., Ji L., Zhao J., Gregan F., Ali S., Sajadi A., Song B., Sigel H., Stability of metal ion complexes formed with methyl phosphate and hydrogen phosphate, JBIC 1 (1996) 231-238.

[24] Samson E., Lemaire G., Marchand J., Beaudoin J.J., Modeling chemical activity effects in strong ionic solutions, Comput. Mater. Sci. 15 (1999) 285-294.

[25] Sigel H., Interactions of metal ions with nucleotides and nucleic acids and their constituents, Chem. Soc. Rev. 22 (1993) 255-267.

[26] Sigel H., Song B., Solution structures of nucleotide-metal ion complexes. Isomeric equilibria, Met. Ions Biol. Syst. 32 (1996) 135-205.
[27] Torikata Y., Ishihara J., Yano T., Protein coagulation through reversible and irreversible bindings of calcium, Agric. Biol. Chem. 51 (1986) 707-714.

[28] Turner B.L., Paphazy M.J., Haygarth P.M., McKelvie I.D., Inositol phosphates in the environment, Philos. Trans. R. Soc. Lond. B Biol. Sci. 357 (2002) 449-469.

[29] Udabage P., McKinnon I.R., Augustin M.A., Effects of mineral salts and calcium chelating agents on the gelation of renneted skim milk, J. Dairy Sci. 84 (2001) 1569-1575.

[30] Upreti P., Buhlmann P., Metzger L.E., Influence of calcium and phosphorus, lactose and salt-to moisture ratio on cheddar cheese quality: $\mathrm{pH}$ buffering properties of cheese, J. Dairy Sci. 89 (2006) 938-950.

[31] Van Wazer J.R., Chemistry, Interscience publishers, New York, USA, 1958.

[32] Vujicic I., Batra S.C., Deman J.M., Interaction of alkaline earth metal ions with polyphosphates and citrate in the presence and absence of casein, J. Agric. Food Chem. 15 (1967) 403-407.

[33] Vujicic I., deMan J.M., Woodrow I.L., Interaction of polyphosphates and citrate with skimmilk proteins, Can. Inst. Food Sci. Technol. J. 1 (1968) 17-21.

[34] Walstra P., Wouters J.T.M., Geurts T.J., Dairy Science and Technology, CRC press, Boc Raton, USA, 2006. 